\title{
Meningkatkan kemampuan guru untuk menerapkan pembelajaran contextual teaching and learning melalui KKG
}

\author{
Gustini Gustini*) \\ SDN 22 Muara Kandis Kec. Linggo Sari Baganti
}

\begin{tabular}{l} 
Article Info \\
\hline Article history: \\
Received Jun $14^{\text {th }}, 2021$ \\
Revised Jul $24^{\text {th }}, 2021$ \\
Accepted Aug $25^{\text {th }}, 2021$ \\
\hline
\end{tabular}

Keyword:

CTL

$\mathrm{KKG}$

\begin{abstract}
Penelitian tindakan sekolah ini dilakukan sebanyak 2 siklus yang masingmasing siklus terdiri dari 4 kegiatan, yaitu perencanaan (planning), pelaksanaan (acting), pengamatan (observing), dan refleksi (reflecting). Setelah dilaksanakan Penelitian Tindakan Sekolah (PTS) sebanyak 2 kali putaran atau 2 siklus, maka hasil-hasilnya adalah: meningkatkan kemampuan dan ketrampilan guru dalam menerapkan pembelajaran dengan pendekatan Pembelajaran Kontekstual. Hal ini dibuktikan dengan perolehan skor dari siklus satu ke siklus yang lain terjadi kenaikan yang cukup signifikan, yaitu dari siklus I kemampuan guru $(3,03)$, siklus II $(3,77)$ sudah mendekati target ketercapaian kemampuan guru dalam menerapkan pembelajaran kontekstual. Disamping itu peningkatan kemampuan dapat kita lihat dari kenaikan prosentase tingkat kemampuan dari para guru, yaitu: bahwa pada siklus I para guru yang berkemampuan sangat baik masih belum ada atau $0 \%$, pada siklus II naik menjadi 8,57 \%.
\end{abstract}

(C) 2021 The Authors. Published by IICET.

This is an open access article under the CC BY-NC-SA license

(https://creativecommons.org/licenses/by-nc-sa/4.0

\section{Corresponding Author:}

Gustini Gustini,

SDN 22 Muara Kandis Kec. Linggo Sari Baganti

Email: gustini@gmail.com

\section{Pendahuluan}

Belajar akan lebih bermakna jika anak 'mengalami' apa yang dipelajarinya, bukan 'mengetahuinya'. Pembelajaran yang berorientasi target penguasaan materi terbukti berhasil dalam kompetisi 'mengingat' jangka pendek, tetapi gagal dalam membekali anak memecahkan persoalan dalam kehidupan jangka panjang. Dan itulah yang terjadi di kelas-kelas sekolah kita. Dewasa ini ada kecenderungan untuk kembali pada pemikiran bahwa anak akan belajar lebih baik jika lingkungna diciptakan alamiah. Pembelajaran Kontekstual atau disebut dengan Contextual Teaching and Learning (CTL), merupakan konsep belajar yang membantu guru mengaitkan antara materi yang diajarkannya dengan situasi dunia nyata siswa dan mendorong siswa membuat hubungan antara pengetahuan yang dimilikinya dengan penerapannya dalam kehidupan mereka sebagai anggota keluarga dan masyarakat.

Dalam upaya itu mereka memerlukan guru sebagai pengarah dan pembimbing. Dalam kelas kontekstual, tugas guru adalah membantu siswa mencapai tujuannya. Maksudnya guru lebih banyak berurusan dengan strategi daripada memberi informasi. Tugas guru mengelola kelas sebagai sebuah tim yang bekerja bersama untuk menemukan sesuatu yang baru bagi anggota kelas (siswa). Sesuatu yang baru (pengetahuan dan ketrampilan) datang dari menemukan sendiri bukan dari apa kata guru. Begitulah peran guru di kelas yang dikelola dengan pendekatan kontekstual. Untuk melaksanakan tugas ini, guru juga perlu adanya pembinaan dan kontrol baik oleh kepala sekolah maupun oleh Kepala sekolah 
Namun demikian sejauh ini pendidikan kita masih didominasi oleh pandangan bahwa pengetahuan sebagai perangkat fakta-fakta yang harus dihafal. Kelas masih berfokus pada guru sebagai sumber utama pengetahuan, kemudian ceramah menjadi pilihan utama strategi belajar.

Berdasarkan uraian di atas, maka penulis selaku Kepala sekolah tertarik untuk mengadakan Penelitian Tindakan Sekolah yang berjudul: "Upaya Meningkatkan Kemampuan Guru untuk Menerapkan Pembelajaran Kontekstual Melalui KKG di SDN 22 Muara Kandis Kec. Linggo sari Baganti ”.

\section{Metode}

Penelitian Tindakan Sekolah dilakukan di SDN 22 Muara Kandis Kec. Linggo sari Baganti, Penelitian di lakukan selama 2 Bulan yaitu pada bulan Juli 2020 - Agustus 2020 pada semester I Tahun Pelajaran 2020/2021. Subyek penelitian yaitu guru SDN 22 Muara Kandis Kec. Linggo sari Baganti yang berjumlah 10 orang guru yang ikut dalam kegiatan KKG di sekolah. Sesuai dengan bentuk dan sumber data yang dimanfaatkan dalam Penelitian Tindakan Kelas, maka teknik pengumpulan data yang digunakan dalam penelitian ini adalah:

1. Wawancara

Wawancara adalah merupakan pertemuan antara dua orang untuk bertukar informasi dan ide melalui tanya jawab sehingga dapat dikonstruksikan makna dalam suatu topik tertentu. Wawancara yang dilakukan peneliti bersifat lentur, tidak terstruktur ketat, tidak dalam suasana formal dan dapat dilakukan berulang pada informan yang sama secara lebih mendalam. Dengan wawancara mendalam berharap akan memperoleh informasi yang rinci dan mendalam. Dengan wawancara ini, akan diperoleh data terutama mengenai minat siswa dan kondisi.

\section{Observasi}

Observasi merupakan teknik monitoring, dimana peneliti (pengamat) dalam penelitian ini berperan aktif mengamati pembelajaran di kelas. Observasi ini digunakan untuk mendapatkan data-data yang diperlukan sebagai dasar untuk melakukan penelitian yang lebih lanjut, dan dengan observasi ini akan diperoleh datadata mengenai seluruh aktivitas atau tingkah laku siswa dalam pembelajaran yaitu data tentang sikap dan aktivitas siswa.

3. Tes

Tes adalah serentetan pertanyaan atau latihan serta alat lain yang digunakan untuk mengukur kemampuan, pengetahuan intelegensi, kemampuan atau bakat yang dimiliki individu atau kelompok. Tes dalam penelitian ini digunakan untuk mengetahui perkembangan atau keberhasilan pelaksanaan tindakan berupa tes tertulis dan tes proses dalam penguasaan konsep. Data yang diperoleh dari pelaksanaan tes adalah hasil nilai dari tes yang diberikan kepada siswa.

Dalam penelitian tindakan kelas ini, teknik analisis data yang digunakan adalah teknik deskriptif. Data yang dianalisis berupa rata-rata dan prosentase hasil belajar siswa. Data yang diperoleh disajikan dalam bentuk tabel. Rancangan penelitian yang dipilih yaitu model siklus yang dilakukan secara berulang dan berkelanjutan (siklus spiral); artinya semakin lama diharapkan semakin meningkat perubahan/pencapaian hasilnya. Model siklus mengikuti rencana, tindakan, observasi, dan refleksi :

1. Tahap Perencanaan Tindakan

Rencana tindakan disusun berdasarkan masalah yang hendak dipecahkan dan hipotesis tindakan yang diajukan. Ini berarti, suatu tindakan harus dilakukan agar terjadi perubahan ke arah yang diharapkan.

2. Tahap Pelaksanaan Tindakan Jenis tindakan yang dilakukan hendaknya selalu didasarkan atas pertimbangan teoritis dan empirik agar hasil yang diperoleh berupa peningkatan kinerja dan hasil program adalah optimal.

3. Tahap Observasi

Dalam observasi, data atau informasi yang dikumpulkan adalah data tentang proses berupa perubahan kinerja pembelajaran dan jenis data yang dikumpulkan cenderung didominasi data kualitatif.

4. Tahap Refleksi

Pada dasarnya refkleksi merupakan kegiatan analisis-sintesis, interpretasi, dan eksplanasi (penjelasan) terhadap semua informasi yang didapatkan hendaknya dikaji dan dipahami bersama. Informasi yang terkumpul perlu diurai, dicari kaitan antara yang satu dengan yang lainnya, dibandingkan dengan pengalaman sebelumnya, dikaitkan dengan teori tertentu dan/atau hasil penelitian yang relevan. Melalui proses refleksi yang mendalam dapat ditarik kesimpulan yang mantap dan tajam. Refleksi 
merupakan bagian yang amat penting untuk memahami dan memberikan makna terhadap proses dan hasil (perubahan) yang terjadi sebagai akibat adanya tindakan (intervensi) yang dilakukan.

Sumber data guru berasal dari hasil observasi selama proses mengajar yang dilaksanakan oleh kepala sekolah sebagai observer selama pelaksanaan siklus pertama dan kedua.

Prosedur/langkah-langkah Penelitian Tindakan Kelas ini terdiri dari siklus-siklus. Tiap siklus dilaksanakan sesuai dengan perubahan yang dicapai seperti yang telah didesaian dalam faktor-faktor yang diselidiki. Prosedur pelaksanaan Penelitian Tindakan Kelas ini setiap siklus meliputi: perencanaan, pelaksanaan tindakan, observasi, dan refleksi.

a.Siklus I

1) Perencanaan Tindakan

a) Guru membuat Rencana Pelaksanaan Pembelajaran (RPP)

b) Menyediakan alat dan media pembelajaran.

c) Membuat instrumen observasi.

d) Membuat lembar evaluasi pembelajaran.

2) Pelaksanaan Tindakan

a) Guru menerapkan rencana pembelajaran dengan menggunakan model pembelajaran CTL Saat KKG.

b) Guru Mengajar dengan pendekatan CTL.

3) Observasi

Pelaksanaan observasi dilakukan oleh guru peneliti bersama supervisor. Tugas supervisor adalah mengamati kegiatan guru selama proses KKG berlangsung.

4) Refleksi

Kepala (peneliti) mengadakan evaluasi dan refleksi dari kegiatan perencanaan, pelaksanaan, dan observasi yang dikolaborasikan dengan Supervisor Penelitian. Hasil evaluasi dan refleksi siklus I digunakan sebagai acuan dalam menyusun perencanaan pada siklusII.

b.Siklus II

1) Perencanaan Tindakan

Berdasarkan hasil refleksi pada siklus I, Kepala (peneliti) mengadakan perbaikan Rencana

Pelaksanaan Pembelajaran terutama pada peran guru.

2) Pelaksanaan Tindakan

a)Guru menerapkan rencana pembelajaran dengan menggunakan model pembelajaran kontektual lebih ditingkatkan lagi.

b) Guru mengajar dengan pendekatan CTL.

3) Observasi

Pelaksanaan observasi hampir sama dengan siklus I, yaitu Kepala (peneliti) bersama supervisor mengamati kegiatan guru selama proses KKG berlangsung.

4) Evaluasi dan Refleksi

Mengadakan evaluasi dan refleksi dari kegiatan perencanaan, pelaksanaan, dan observasi yang dikolaborasikan dengan Supervisor Penelitian. Jika hasil evaluasi dan refleksi siklus II belum memenuhi indikator kinerja penelitian maka dapat dilanjutkan ke siklus III, namun jika sudah memenuhi indikator kinerja penelitian maka dapat diakhiri pada siklus II.

\section{Hasil dan Pembahasan}

\section{Hasil Penelitian}

\section{Siklus I}

Penelitian siklus I di laksnanakan pada 5 Juli 2020. Sebagai gambaran hasil penelitian dengan subyek 10 orang guru di SDN 22 Muara Kandis Kec. Linggo sari Baganti. Dapat di lihat bahwa kemampuan para guru di SDN 22 Muara Kandis Kec. Linggo sari Baganti dalam menerapkan pembelajaran kontekstual pada siklus I masih rendah, yaitu dengan rata-rata 3,03 atau katagori 'cukup'. Jenis kemampuan yang paling rendah adalah melakukan inkuiri dalam pembelajaran, dengan rata-rata 2,4 (kurang). Sedangkan jenis kemampuan yang paling menonjol adalah Adanya Authentic Assesment dalam proses dan akhir pembelajaran dengan skor 3,5.

Data Persentase Skor Hasil Penerapan Pembelajaran Kontekstual Pada SiklusI yang berkemampuan sangat baik $0 \%$, baik $27,14 \%$, cukup $50 \%$, kurang $21,43 \%$, dan sangat kurang 1,43\%.Dengan mendasarkan 
hasil penelitian pada siklus I ini, menunjukkan bahwa kemampuan guru dalam pembelajaran kontekstual belumlah sesuai harapan, oleh sebab itu perlu dacari sebab-sebabnya dan kemudian diperbaiki pada siklus II

\section{Siklus II}

Siklus ke II di lakukan pada 20 Juli 2021, Sebagai gambaran hasil penelitian dengan subyek 10 orang guru di SDN 22 Muara Kandis Kec. Linggo sari Baganti, dapat kita lihat bahwa kemampuan para guru di SDN 22 Muara Kandis Kec. Linggo sari Baganti dalam menerapkan pembelajaran kontekstual pada siklus II sudah ada peningkatan, yaitu dengan rata-rata 3,77 atau katagori 'cukup'. Jenis kemampuan yang paling rendah adalah masih tetap namun sudah ada peningkatan jika dibanding dengan siklus I yaitu melakukan inkuiri dalam pembelajaran, dengan rata-rata pada siklus I 2,4 (kurang) menjadi 3,2. Sedangkan jenis kemampuan yang paling menonjol adalah Adanya Authentic Assesment dalam proses dan akhir pembelajaran dengan skor 4,3, dan hal ini juga meningkat jika dibandingkan dengan siklus I dengan skor 3,5. Disamping itu juga terjadi peningkatan skor di semua jenis kemampuan guru. Sedangkan dari Tabel 4, dapat kita lihat bahwa pada siklus II yang berkemampuan sangat baik $8,57 \%$, baik $61,43 \%$, cukup $28,57 \%$, kurang $2,66 \%$, dan sangat kurang $0,0 \%$.

Dengan mendasarkan hasil penelitian pada siklus II ini, menunjukkan bahwa kemampuan guru dalam pembelajaran kontekstual sudah terjadi peningkatan. Namun demikian peningkatan tersebut belumlah sesuai harapan, oleh sebab itu perlu dacari sebab-sebabnya dan kemudian diperbaiki pada siklus III.

Hasil penelitian tindakan pada siklus I menunjukkan bahwa kemampuan para guru di SDN 22 Muara Kandis Kec. Linggo sari Baganti dalam menerapkan pembelajaran kontektual masih rendah. Hal ini disebabkan para guru masih sangat minim pemahamannya tentang pembelajaran kontekstual. Hal ini dapat dilihat pada Tabel 1, bahwa kemampuan rata-rata para guru di SDN 22 Muara Kandis Kec. Linggo sari Bagantidalam menerapkan pembelajaran kontekstual dengan skor rata-rata 3,03 atau katagori 'cukup'. Jenis kemampuan yang paling rendah adalah melakukan inkuiri dalam pembelajaran, dengan rata-rata 2,4 (kurang). Sedangkan jenis kemampuan yang paling menonjol adalah Adanya Authentic Assesment dalam proses dan akhir pembelajaran dengan skor 3,5 .

Tingkat rendahnya kemampuan guru dalam menerapkan pembelajaran kontekstual pada siklus I ini juga tergambar dari Tabel 2, bahwa para guru belum ada yang berkemampuan sangat baik atau $0 \%$, yang berkemampuan baik rata-rata $27,14 \%$, cukup $50 \%$, kurang $21,43 \%$, dan yang berkemampuan sangat kurang $1,43 \%$.

Dengan mendasarkan hasil penelitian pada siklus I ini, menunjukkan bahwa kemampuan guru dalam pembelajaran kontekstual belumlah sesuai harapan, oleh sebab itu perlu dacari sebab-sebabnya dan kemudian diperbaiki pada siklus II.

Hasil penelitian pada siklus II, telah terjadi peningkatan semua jenis kemampuan guru dalam pembelajaran kontekstual. Hal ini dapat dilihat pada Tabel 3 dan Tabel 4di atas. Pada siklus II ini kemampuan para guru di SDN 22 Muara Kandis Kec. Linggo sari Baganti dalam menerapkan pembelajaran kontekstual sudah ada peningkatan, yaitu dengan rata-rata dari 3,03 menjadi 3,77 (naik $24.42 \%$ ). Jenis kemampuan yang paling rendah adalah masih tetap namun sudah ada peningkatan jika dibanding dengan siklus I yaitu melakukan inkuiri dalam pembelajaran, dengan rata-rata pada siklus I 2,4 menjadi 3,2 (naik $33.33 \%$ ). Sedangkan jenis kemampuan yang paling menonjol adalah Adanya Authentic Assesment dalam proses dan akhir pembelajaran dengan skor 4,3 , dan hal ini juga meningkat jika dibandingkan dengan siklus I dengan skor 3,5 (naik $22.86 \%$ ). Disamping itu juga terjadi peningkatan skor di semua jenis kemampuan guru.

Peningkatan kemampuan guru dalam menerapkan pembelajaran kontekstual pada siklus II ini juga tergambar dari Tabel 4, yaitu bahwa guru yang berkemampuan sangat baik meningkat dari $0 \%$ menjadi 8,57 \% (naik $8.57 \%$ ), yang berkemampuan baik naik dari 27,14 menjadi 61,43\% (naik 34,29 \%), yang berkemampuan cukup menurun dari $50 \%$ menjadi $28,57 \%$, yang berkemampuan kurang menurun dari $27,14 \%$ menjadi $2,66 \%$, dan yang berkemampuan sangat kurang juga menurun dari $1,43 \%$ menjadi $0,0 \%$.

Dengan mendasarkan hasil penelitian pada siklus II ini, menunjukkan bahwa kemampuan guru dalam pembelajaran kontekstual sudah terjadi peningkatan. Namun demikian peningkatan tersebut belumlah sesuai harapan.

Dalam menerapkan pembelajaran kontekstual pada siklus sudah ada peningkatan yang cukup signifikan, yaitu dari siklus I $(3,03)$, siklus II $(3,77)$. Jika diprosentase maka kenaikan dari siklus I adalah $47.52 \%$, kenaikan dari siklus II $18.57 \%$ atau katagori 'baik', dan bahkan sudah mendekati target ketercapaian kemampuan guru dalam menerapkan pembelajaran kontekstual. Jenis kemampuan yang paling rendah adalah masih tetap namun sudah ada peningkatan yang cukup berarti jika dibanding dengan siklus II yaitu melakukan inkuiri dalam pembelajaran, dengan rata-rata pada siklus II 3,2 (cukup) menjadi 3,9 (cukup). 
Sedangkan jenis kemampuan yang paling menonjol adalah dua kemampuan yaitu Adanya Questioning dalam proses pembelajaran dan Adanya Authentic Assesment dalam proses dan akhir pembelajaran dengan skor masing-masing 4,8, dan hal ini juga meningkat jika dibandingkan dengan siklus II dengan skor 4,0 dan 4,3. Disamping itu juga terjadi peningkatan skor di semua jenis kemampuan guru jika dibandingkan dengan siklus II.

Pada siklus II guru yang berkemampuan baik mencapai 47,14 \% (menurun 14,29\% jika dibanding siklus I), guru yang berkemampuan cukup 2,86\% (menurun 25,71\% jika dibanding siklus II), guru yang berkemampuan kurang menurun dari 2,86 pada siklus II menjadi 0,00 \% pada Untuk semakin memperjelas keberhasilan penelitian tindakan ini, berikut ditampilkan perbandingan kemampuan guru dalam pemenerapkan pembelajaran kontekstual antara siklus I, II,

Dengan mendasarkan hasil penelitian pada siklus II ini, menunjukkan bahwa kemampuan guru dalam pembelajaran kontekstual sudah terjadi peningkatan yang cukup signifikan, dan bahkan sudah mendekati ketercapaian target yang diharapkan dalam penelitian tindakan ini. Dengan demikian penelitian tindakan yang sudah sampai pada siklus III ini dianggap sudah cukup dan tidak perlu lagi dilakukan siklus IV.

\section{Simpulan}

Berdasarkan perkembangan upaya-upaya yang dilakukan oleh Kepala sekolah melalui teknik $K K G$ kepada para guru di SDN 22 Muara Kandis Kec. Linggo sari Baganti dalam penerapan pendekatan Pembelajaran Kontekstual (CTL), maka peneliti dapat menyimpulkan sebagai berikut: 1) Upaya Kepala sekolah dalam kegiatan KKG kepada guru mampu meningkatkan kemampuan dan ketrampilan guru dalam menerapkan pembelajaran dengan pendekatan Pembelajaran Kontekstual; 2) Semakin intensif melakukan KKG bersama para guru mata pelajaran oleh Kepala sekolah, semakin meningkatkan kemampuan guru dalam menerapkan pendekatan pembelajaran kontekstual; 3) Pendekatan pembelajaran kontekstual sangat sesuai untuk menumbuhkan kekritisan siswa dalam menganalisis, membedakan, menggeneralisasikan, dan menghipotesis permasalahan

\section{Referensi}

Bolla, JL, (1980), Supervisi Klinik, Direktorat Pendidikan Tinggi, Departemen Pendidikan dan Kebudayaan, Jakarta, P3TK.

Depdikbud, (1997), Alat Penilaian Kemampuan Guru, Dirjen Dikdasmen, Direktorat Pendidikan Guru dan Tenaga Teknis, Jakarta, Proyek Peningkatan Mutu Guru SD setara D-II.

Departemen Pendidikan Nasional (2002), Pendekatan Kontekstual (Contextual Teaching and Learning), Jakarta.

Departemen Pendidikan Nasional. (2007), Petunjuk Teknis Penelitian Tindakan Sekolah, Jakarta.

Hariwung, A.J., (1981), Supervisi Pendidikan, Jakarta, Depdikbud.

Imron, A. (1999), Pembinaan Guru di Indonesia, Jakarta, Dunia Pustaka Jaya.

Muhajir, N. (1996). Pedoman Penelitian Tindakan Kelas (PTK) Bagian Ke 4 : Analisis dan Refleksi. Dirjen Dikti Depdikbud Proyek Pendidikan Tenaga Akademik. BP3GSD. UP3SD UKMP iKIP Yogyakarta.

Pidarta, M. (1992), Pemikiran Tentang Supervisi Pendidikan, Jakarta, Bumi Aksara.

Sahertian, P.A. (2000), Konsep Dasar dan Teknik Supervisi Pendidikan, Jakarta, Reineka Cipta. 